3s. $6 d$. and half a hundredweight of coke not inore than $6 d$. (at 20s. a ton), or only one-seventh part of the price of gas.

If heating gas was supplied at a much cheaper rate, it would in many cases be advantageous to substitute incombustible matter, such as balls of asbestos, for the coke or anthracite. The consumption of gas would in that case have to be increased very considerably, but the economical principle involved (that of heating the air of combustion by conduction from the back of the grate) would still apply, and produce economical results as compared with those obtained by the gas-asbestos arrangements hitherto used.

To illustrate the efficiency of this mode of heating the in-com. ing air by what is called waste heat, I will show you another application of the same principle which I have made very recently to the combastion of gas for illuminating purposes.

(To be continued.)

\section{THE RECENT SEVERE WEATHER}

$\mathrm{IN}$ a recent contribution to the literature of meteorology $\mathrm{Mr}$

E. J. Lowe, F.R.S., endeavours to prove that droughts and great frosts are periodical, occurring at intervals of between eleven and twelve year's. In support of this theory be remarks : " There can be no reasonable doubt that the cycles are more than eleven years and less than twelve (more nearly eleven than twelve)," and a table of "great frosts" is given, from which we take the dates for the present century in the same order as printed.

$$
\begin{array}{l|l|l}
1801-2 & 1819-20 & 1860-61 \\
1813-14 & 1837-38 & 1856-57 \\
1810-I 1 & 1840-41 & 1870-71
\end{array}
$$

The present year may now be added to the above list.

It will be noticed that there are some variations in the lengths of the intervening periods, but there is at the same time a distinct recurrence of eleven-year epochs.

The great frost of the month just ended will doubtless form one of the main features in the meteorology of the nineteenth century. In the table below are given the average temperatures of the United Kingdom for the three weeks ended January Io, I7, and 24 of the present year, together with the temperatures for the same weeks ended January $\mathbf{1 2}, \mathbf{1 9}$, and $\mathbf{2 6}$ of the year 1880. Each year the average for these periods was below the mean seasonal value. The deficiency is given in the fifth and

\begin{tabular}{|c|c|c|c|c|c|c|c|c|c|c|}
\hline \multirow[b]{2}{*}{ Districts. } & \multicolumn{4}{|c|}{$\underbrace{188 \mathrm{r} .}$} & \multirow{2}{*}{ 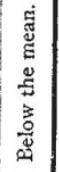 } & \multicolumn{4}{|c|}{ r88o. } & \\
\hline & $\begin{array}{l}\dot{\vec{J}} \\
\text { घँ } \\
\vec{w}\end{array}$ & 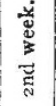 & 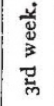 & 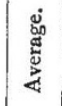 & & 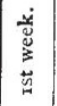 & 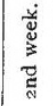 & 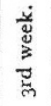 & 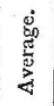 & 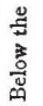 \\
\hline $\begin{array}{l}\text { Scotland, East ...... } \\
\text { England, N.E...... } \\
\text { England, East ....... } \\
\text { Midland Counties... } \\
\text { England, South...... } \\
\text { Scotland, West ..... } \\
\text { England, N.w...... } \\
\text { England, S.W. ....... } \\
\text { Ineland, North ...... } \\
\text { Ireland, South ...... } \\
\text { London }\end{array}$ & $\begin{array}{l}30 \\
30 \\
35 \\
36 \\
34 \\
37 \\
33 \\
35 \\
38 \\
35 \\
35 \\
38 \\
37 \\
37\end{array}$ & $\begin{array}{l}24 \\
24 \\
23 \\
23 \\
21 \\
26 \\
23 \\
25 \\
31 \\
24 \\
27 \\
24.2\end{array}$ & $\begin{array}{l}25 \\
25 \\
25 \\
24 \\
22 \\
26 \\
26 \\
27 \\
28 \\
26 \\
27 \\
24.8\end{array}$ & $\begin{array}{l}26^{\circ} \cdot 3 \\
27.7 \\
27.7 \\
25.7 \\
29.7 \\
27.3 \\
29.0 \\
32.3 \\
28.3 \\
30^{\circ} \cdot 7 \\
28.8\end{array}$ & 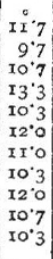 & \begin{tabular}{|l|}
38 \\
37 \\
37 \\
35 \\
35 \\
35 \\
40 \\
38 \\
39 \\
42 \\
43 \\
43.2 \\
34
\end{tabular} & $\begin{array}{l}34 \\
32 \\
32 \\
33 \\
32 \\
34 \\
34 \\
38 \\
37 \\
37 \\
32 \cdot 4\end{array}$ & $\begin{array}{l}34 \\
32 \\
31 \\
29 \\
30 \\
33 \\
33 \\
35 \\
3 \pi \\
35 \\
29 \\
29\end{array}$ & 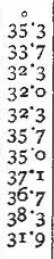 & $\begin{array}{l}2 \% 3 \\
4 \% 3 \\
6 \cdot \% \\
6 \% 7 \\
7 \% \\
4 \% \\
5 \% \\
6 \% 3 \\
4 \cdot 3 \\
3 \cdot 3 \\
7 \cdot 3\end{array}$ \\
\hline
\end{tabular}
tenth columns.

The weather during the above periods was cold in both years, and the deficiency of solar heat is more noticeable, if the figures of the second and third weeks in each year are compared. On several days bright sunshine occurred for several hours, yet at some stations the sunshine was so weak as to fail to mark the recording cards of Prof. Stokes's sunshine recorders.

The weather over the whole of north-western Europe has been generally intensely cold, and on January 28 the temperature at Haparanda (extreme north of Gnlf of Bothnia) was reported as being $60^{\circ} \mathrm{F}$. below freezing point.

H. W. C.

\section{THE AURORA OF FANUARY $3 \mathrm{I}$}

$W E$ have received the following communications on the recent brilliant display of aurora :-

HAVING noticed an auroral light through the mist on the evening of January 30 , I looked out last evening, the 3 rst, and saw what to me at least was a new appearance. There was a strong yellowish-white auroral light in the north, with an uneven boundary-not a well-defined arch. From it there arose, at intervals of a minute or two, what looked like wisps of luminous mist of an elliptical form, with their longer axes east and west. These chased one another towards the zenith, appearing ? and disappearing with great rapidity, so that one could hardly say "look!" before they had vanished. Sometimes three or four were flashing out at once. They were of large size, and being unaccustomed to the description of such objects, I know not how to describe their size. They must however have subtended horizontally angles of $45^{\circ}$ and more at the eye. This appearance lasted, from the time I first looked out at about 6h. 45m., for about ten minutes or less, and then the appearance gave place to ordinary streamers, yellowish-white at their base and rosy towards their summits.

The flashing lights which I have mentioned suggested to me this idea : One has seen two men shaking a carpet held at two adjoining corners. Their strokes not exactly coinciding, an irregular, undulatory movement is produced, something like the waves of a chopping sea. If a stratum of something was in such a state of undulation above the atmosphere, and became visibly luminous where the crests of the undulations dipped down into the atmosphere, it would produce the kind of appearance that $I$ saw.

\section{Harlton Rectory, Cambridge, February}

OSMOND FISHER

LEST the magnificent auroral display of last evening has not been generally visible, the following short account of it, as witnessed here, may not be unacceptable to the readers of NATURE.

At about 6.15 p.m. indications of the disturbance were noticed in an unusually bright appearance of the sky from the north-east to north-west by west, the light being white, and similar in character to that reflected from the upper part of a bank of fog By 6.25 the upper limit of this phenomenon had gradually changed into a number of bands, alternately bright and dark, but not well defined, which after another short interval disappeared in a change of the light to a very ruddy tint, accompanied by a kind of throbbing in the north, exactly like rapid repetitions of faint lightning. At this period a great number of parallel bands of light of a beautifully clear salmon tint were extended from the ruddy bank in a southerly direction, those from the north passing beyond the zenith, and losing their definition in a diffused patch of light of the same colour. These bands slowly faded away, but were succeeded by a similar and equally beautiful display at from ten to fifteen minutes later.

About seven o'clock I walked two and a half to three miles in a northerly direction, and found in ascending a slight hill that the fog was sufficiently thick to obscure the stars. This I imagine explains the peculiar bank and thick appearance of the light near the horizon.

The whitish illumination in the same quarter of the sky was still visible at 12 p.m.

Wick near Arundel, February $\mathrm{r}$ JOHN HARMER

A BRILLIANT aurora borealis has been visible here this evening. It commenced at twenty minutes to seven, extending from westnorth-west to a little east of north. The western part was of a deep ruddy colour, extending (at a rough estimate) some 35 or 40 degrees from the horizon, and varied by long white streamers, one of which-nearly due north-reached to within $r_{5}$ or 20 degrees of the zenith. I was unable to watch it for more than a few minutes, but at half-past ten the sky in the same direction was still remarkably bright.

Kelly College, Tavistock, January 3 I

A VERY brilliant auroral display was visible here last night. There was a short heavy shower of hail and rain at six o'clock, and the sky was entirely overclouded. Thirty minutes later the sky was again clear, and the northern horizon was beautifully illuminated, and broad quivering bands of light stretched from thence upward beyond the zenith, some in unbroken continuity, while others were broken up. Not connected with these rays, and on the south side of the zenith, were frequent flashes of light, usually crescentic in form. The light near the horizon was silvery and moonlight like, but hígher up it became much ruddier. I watched the aurora from 6.30 till 7 , when I was obliged to go in-doors till 10.30 , and then able to observe it again. At that time the light near the northern horizon had greatly increased in brightness, but fewer bands extended 